\title{
Productivity beyond density: A critique of management models for reindeer pastoralism in Norway
}

\author{
Andrei Marin ${ }^{1 *}$, Espen Sjaastad ${ }^{1}$, Tor A. Benjaminsen ${ }^{1}$, Mikkel Nils M. Sara ${ }^{2}$ and Erik Johan Langfeldt Borgenvik ${ }^{1}$
}

\begin{abstract}
The official governance of the reindeer pastoralist system in the north of Norway relies overwhelmingly on one central argument: that in order to maintain a sustainable system, maximum numbers and densities of reindeer, as well as certain herd structures, should be upheld. If these indicators are ignored, the argument goes, the consequences are resource degradation and economic collapse. Even though this argument has been challenged by both researchers and reindeer herders across Fennoscandia, it continues to dominate management policies and practice. Here we set out to investigate the validity of the premise that there is a strong relationship between density and carcass weights over the whole of Finnmark, based on official data. We find that although the relationship is present, its explanatory power is not very strong in a variety of circumstances and propose that it therefore cannot be used to frame important governance policies for the whole system. We also critically reflect on the model's goal of high productivity per capita of reindeer (high carcass weight). We suggest that productivity per area unit can be at least as relevant as carcass weights and perhaps a better indicator for pastoralist systems in general. For the Finnmark pastoralist system, we argue, a measure of productivity in kilogrammes per square kilometer reveals a different picture: rather than being a failed system marred by suffering animals and low economic returns, reindeer herding in Western Finnmark becomes the most productive in Norway. This shift of focus is likely relevant for other pastoralist systems where governance is premised on similar arguments.
\end{abstract}

Keywords: Reindeer, Sámi, Norway, Pastoralism, Non-equilibrium, Density dependence, Climate change, NAO, Political ecology

\section{Introduction}

During the 1970s, the Norwegian Ministry of Agriculture implemented a series of large-scale initiatives aimed at modernizing the Sámi reindeer pastoralist system, which was regarded as inefficient. These initiatives led eventually to a production model informally known as the Røros model, whose principles and assumptions have been framing management policies and public perceptions to this day. The model recommended the annual slaughter in the autumn of a large proportion of the

\footnotetext{
* Correspondence: amarin@nmbu.no

${ }^{1}$ Department of International Environment and Development Studies

(Noragric), Norwegian University of Life Sciences, Aas, Norway

Full list of author information is available at the end of the article
}

reindeer calves born in the spring in order not to overstock the winter pastures widely regarded as a scarce resource.

Later on, based on research on reindeer herds in the Røros area, the model used empirical evidence linking the carcass weight of reindeer to the stocking densities. It showed that reindeer herds with low densities and a high percentage of does had higher carcass weights. It therefore proposed a management model aimed at: slaughtering calves, low stocking densities, and the establishment of thresholds for the highest number of reindeer allowed in a given area. These are in no way mere abstract development plans for the Norwegian reindeer pastoralism. In the government magazine 
'Reindeer Governance News' (Reindrifstnytt), one can often read articles like: 'The Reindeer Herding Authority clarifies: to increase your profitability slaughter more calves!' (Reindriftsnytt 2013). Routinely, the official advice relies on the assumptions that there are maximum numbers and densities of reindeer as well as optimal herd structures, which, if respected, lead to high productivity and profit and, if ignored, lead to resource degradation and economic collapse. This is the keystone argument on which many of the management policies (be they supportive or punitive) rely. ${ }^{1}$ Yet, this argument has been challenged by both researchers and reindeer herders not only in Norway but also in other reindeer herding systems in Fennoscandia (e.g. Tyler 2010; Benjaminsen et al. 2015; Johnsen et al. 2017; Uboni et al. 2016; Helle and Kojola 2006; Lundqvist 2007).

This article has therefore a twofold aim. First, we seek to test the strength of the dominant density-dependence model based on the best official data available. We accomplish this by analysing a more extensive dataset than that the original model was based on. We show that the model places too much trust in density as the explanatory variable for the dynamics of the reindeer system. Second, we critically examine the validity of the assumptions underlying the model, including assumptions about ecology, appropriate production goals, and the links between them. We propose a different way of conceiving of productivity in the reindeer pastoral system. If we look at productivity in terms of weight per unit of territory $\left(\mathrm{kg} / \mathrm{km}^{2}\right)$, rather than weight per slaughtered animal, the system appears more productive, calling into question many of the implicit assumptions of the present management system.

\section{Study area}

Reindeer husbandry is practised on $40 \%$ of Norway's land area, in forty municipalities. Nevertheless, most of the practitioners (2200 out of a total of 3000$)$ and reindeer (185,000 out of 250,000 as per January 2019) are located in the county of Finnmark (Regjeringen 2019). Finnmark is the northernmost, largest, and least populated county of Norway, where the indigenous Sámi population has been practising mobile reindeer husbandry for several hundred years. The current form of reindeer pastoralism became common in Finnmark during the eighteenth century (Bjørklund 2013), and it entails large-scale seasonal movements between winter pastures (a cold, dry mountain plateau) inland and summer pastures (milder and moist) on the coast and islands. The autumn/spring areas are used for important

\footnotetext{
${ }^{1}$ For example, herders who slaughter calves and keep to the recommended numbers and herd structure receive significant subsidies. County authorities can, since 2015, refuse compensation for reindeer lost to protected predators if the reindeer owner is deemed to possess a too large herd.
}

seasonal activities such as calving, autumn round-ups, mating, and castration (Sara 2001) (Fig. 1).

\section{Methodology}

The article uses a historical contextual analysis of Finnmark reindeer pastoralism as a case study, based on a mixed methods approach. First, we employ quantitative statistical analyses of the relationships between carcass weights of reindeer and different explanatory variables (reindeer density, local and regional climate indicators). We used public data provided by the Norwegian Ministry of Agriculture and Food (MAF) on carcass weights, area, reindeer density, slaughter volume, etc. for the period 1980-2017. In addition, we used climate data (precipitation, growing degree days) from public records provided by the Norwegian Meteorological Institute for three coastal weather stations in Finnmark. The $\mathrm{NAO}^{2}$ climate data were retrieved from the NOAA Climate Prediction Centre as the monthly mean index for 19802018. For all quantitative data, we performed simple or multiple ordinary least square regression analyses for different combinations of variables in statistical packages $\mathrm{R}$ and Microsoft Excel. Second, we used qualitative data derived from 47 semi-structured direct interviews performed in Norwegian with pastoralists, government officials, politicians, and researchers during 2012-2015. In addition, we draw on participant observation (about one month), and informal discussions we have had with reindeer herders in the field, and on the life-long practical experience of one of the authors (M.N.M. Sara) as a reindeer herder.

\section{The Røros model}

During the 1930s, a strategy hinging on reforming herd structures toward a high percentage of does and calf slaughtering was introduced in the reindeer herding systems in the Soviet Union, and later on, during the 1960s, in Finland (Holand 2007). The Norwegian Ministry of Agriculture soon decided to follow this trend and recommended a similar model based on high numbers of does, few bucks (Villmo 1967), and slaughtering calves (Fjellheim 1967) and backed it up with a system of subsidies for calf slaughter in 1976-1977. This type of thinking and management model was particularly at odds with the Sámi reindeer herding system present at the time in Norway, as the latter was based on a traditional herd structure that valued particularly draft

\footnotetext{
${ }^{2}$ The North Atlantic Oscillation (NAO) index is a measurement of the oscillations in the atmospheric pressure differences between highpressure areas around the Azores and low-pressure areas around Iceland. A high NAO coefficient results in much snow and higher temperatures during winter, leading to a late start of the growth season (Petorrelli et al. 2005). Weladji and Holand (2003) have also shown that a high NAO reduces calf weights.
} 


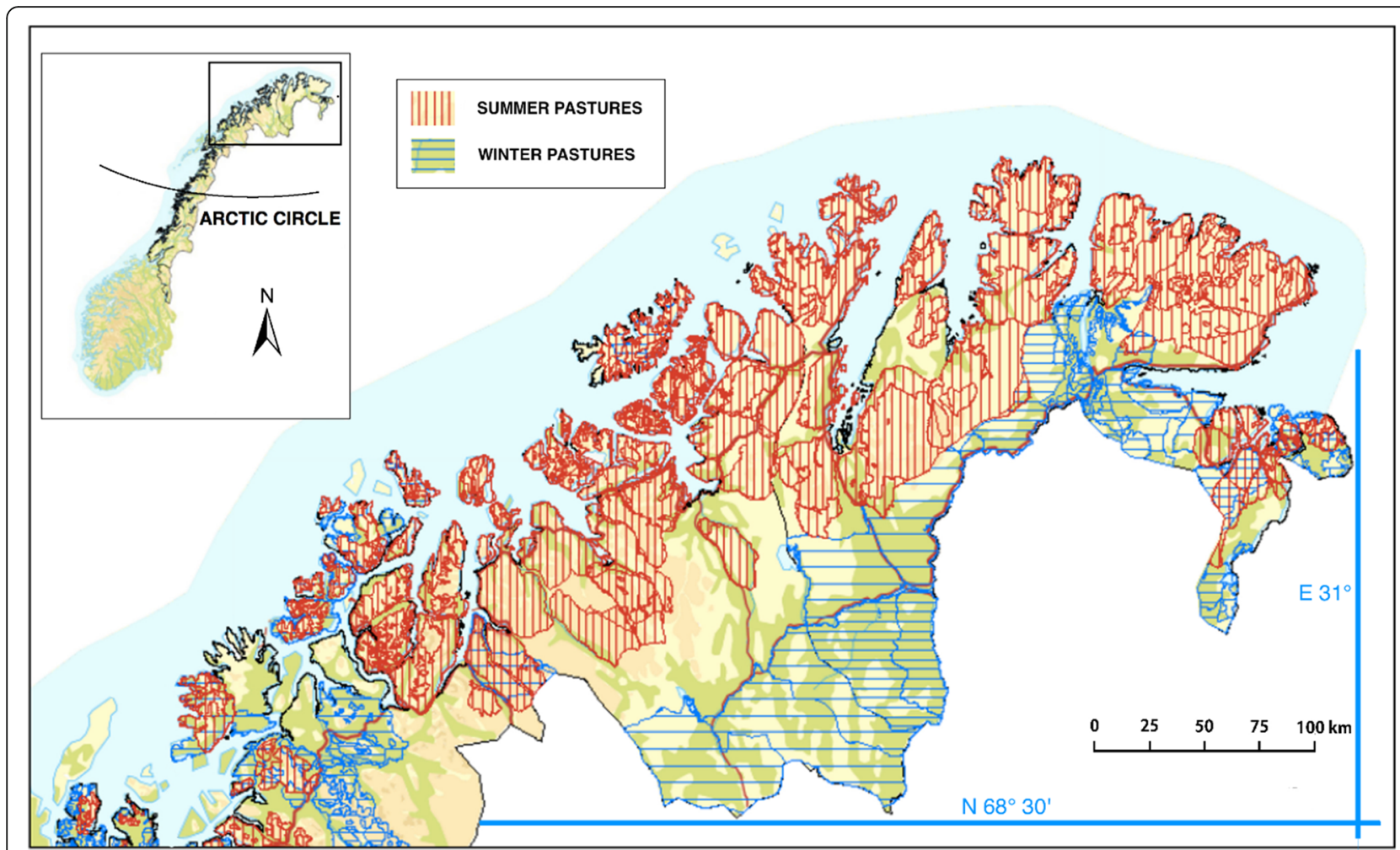

Fig. 1 Summer (vertical shade), autumn/spring (no shade), and winter (horizontal shade) reindeer grazing areas in Finnmark, Norway (source: Benjaminsen et al. 2015)

animals, good diggers such as bucks castrated traditionally (with good muscle mass and dense antlers) (Skum et al. 2016), and in general a herd structure with large phenotypic diversity (ćáppa eallu or 'beautiful herd') perceived as better suited to withstand unexpected critical events (Magga et al. 2011; Borgenvik 2014).

Research aimed at testing the model had started during the early 1970s and was formally referred to as a 'structuring and optimization process' (Lenvik 1990). Informally, it was known as 'the Røros model' because it was largely based on research conducted around the town of Røros in the county of South Trøndelag. The research proposed that the optimal structure of a reindeer herd consisted of relatively few males (bucks) and many heavy females (does) in order to increase the pregnancy rate and reduce calf mortality. Lenvik (1990) argued that there were three relationships one wanted to manage through the model: weight distribution among the does, age distribution among the does, and sex ratio in the herd. Specifically, it was argued that the average weight of the does must increase, as heavier does give births to heavier calves, which leads to higher survival rates among calves. To achieve this, lighter does should be slaughtered. Secondly, the weight of the new-born calves, it was argued, increases with the age of the does until 5 years and decreases as the mothers get older than five. Therefore, the percentage of the most productive (i.e. around 5 years old) does should be as high as possible. Finally, one should slaughter the bucks that are 'unnecessary from a mating point of view' because ' $(. .$.$) they take up pastures that could be$ used by the does' (Lenvik 1990: 31). The percentage of bucks in the flock was therefore recommended to not exceed $10 \%$.

The research around Røros was promoted by the Ministry of Agriculture as a big success and a breakthrough for increasing productivity in the reindeer herding industry.

\section{Critiquing the model-Quantitative assessments The relationship between productivity and density}

Although initially based on data from a county in southern Norway, eventually the model incorporated also data from Western Finnmark in the far north (Lenvik 1990). One of the results of this analysis is presented in Fig. 2. The peak of the curve for total production in Western Finnmark indicates maximum sustainable yield (MSY), which here occurs at a total herd size of 80,000 to 90,000 animals. Beyond this point, growth (or total production) is assumed to decrease. The figure depicts a typical equilibrium situation, where density-dependent processes lead to an increase in mortality and a decrease in reproduction as a result of increased density and higher intra-specific competition for pasture resources. 


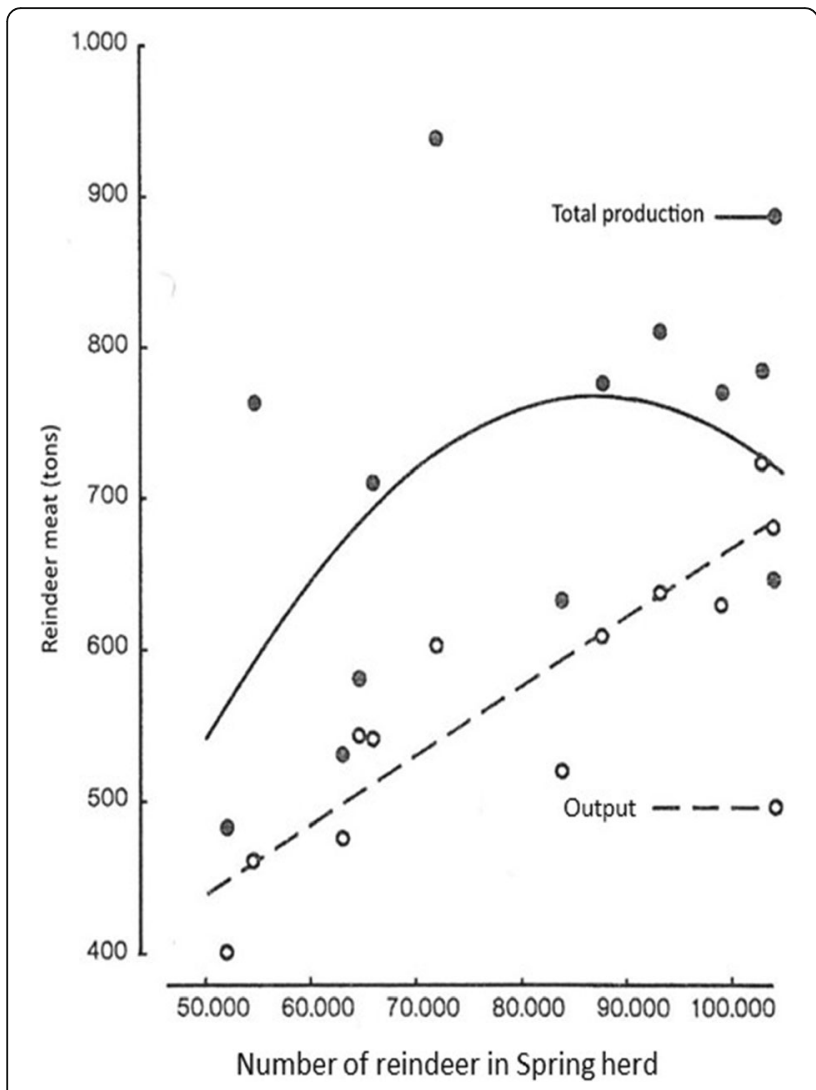

Fig. 2 Productivity in Western Finnmark for the period 1977-1988 expressed as the relationship between the number of reindeer in the Spring herd and (1) output (tonnes from slaughtered reindeer) and (2) total production (in tonnes) (source: Lenvik 1990). Total production is calculated as the sum of the number of reindeer slaughtered each year (output) and the increase in numbers from one year to the next. To derive the total production in tonnes of meat, this sum is multiplied by the average weight of the slaughtered reindeer

One immediate reaction to the empirical material presented here is that there is no obvious pattern to the data points. There are few observations (12), and the data points depart significantly from the regression line. The regression produced an $R^{2}=0.25^{3}$ and was not statistically significant $(P$ value $=0.31)$. The bell-shaped curve for total production can be regarded as the result of forcing the data into a pre-determined polynomial function. In other words, the shape of the curve is given by the chosen model $^{4}$ and is not empirically driven. Nevertheless, it is

\footnotetext{
${ }^{3} R^{2}$ specifies how much of the variation in the carcass weights can be explained by the variation in reindeer density (the latter being derived from the total number of animals divided by the surface area the herds used). In this case, the amount of explained variation was $25 \%$.

${ }^{4}$ The general function is of the type $G=r N-\frac{r}{k} N^{2}$, where $G$ is total production, $N$ is the population size, $r$ is an internal growth rate, and $k$ is the ecological carrying capacity, where mortality equals reproduction. In Lenvik's model (Lenvik 1990), the ecological carrying capacity for Finnmark was 130,000-140,000 reindeer.
}

still instructive to investigate to what extent the empirical data on herd size and productivity in Western Finnmark fit the model.

In Fig. 3, we present again the relationship between population size (total number of reindeer) and total production in Western Finnmark. Data here are for the years 1981-2018, yielding 38 data points, with each data point representing a combination of production and the total number of reindeer in a given year. Total production is measured here in number of animals, rather than in weight as was the case in Lenvik's analysis. ${ }^{5}$ We have used these data to test the strength of a linear and a non-linear (polynomic) regression (following the assumptions of the equilibrium model) relating numbers of reindeer in the herd (counted at the same time as in Lenvik's analysisbefore 1 April each year) and total production. Both the linear and the polynomial regressions have better explanatory power than that of the original model, explaining much more of the variation in the population growth rate ( $R^{2}$ was 0.46 and $0.53^{6}$ respectively).

The relationship between the number of reindeer and total production (the sum of year-on-year growth in number and the number of slaughtered deer) can in reality not be approximated by a straight line rising with the former parameter. This would mean that both total numbers and total production could increase indefinitely. It is also worth noting that compared to Fig. 2, the peak of the polynomic curve (the MSY point) in Fig. 3 occurs at ca. 104,000 animals, while the ecological carrying capacity (at which total production is zero) is at ca. 152,000 animals. A management recommendation based on these numbers would nevertheless be regarded as absurd among many ecologists whether they subscribe to equilibrium or non-equilibrium thinking. To the supporters of equilibrium models, since this number is about the double of what is often considered as a sustainable reindeer population, ${ }^{7}$ it would be seen as exceedingly high. For non-equilibrium supporters, setting such fixed limits does not make sense since the system

\footnotetext{
${ }^{5}$ We argue that this is a more reliable method than that used by official statistics. The latter assumes the slaughtered sample is representative for the entire population-a theoretically questionable assumption. Moreover, the numbers of animals slaughtered for private consumption are estimated based on herders' reports.

${ }^{6}$ Meaning that $46 \%$ and $53 \%$ respectively of the variation in total production can be explained by the variation in the herd size (total number of animals). Compare this to Lenvik's $25 \%$.

${ }^{7}$ Ims and Kosmo (2001) set the highest sustainable reindeer number in Western Finnmark at 66,200 before it was reduced by the state to 64,300 in 2002. In 2017, this number was again increased by the government to 78,150 , which is also approximately what the actual number in early 2020 is believed to have been reduced to through a policy of forced destocking. Johnsen and Benjaminsen (2017) show how the government-defined 'highest number of reindeer' has shifted up and down over time and how the process of setting this number is a function of politics more than of scientific evidence.
} 


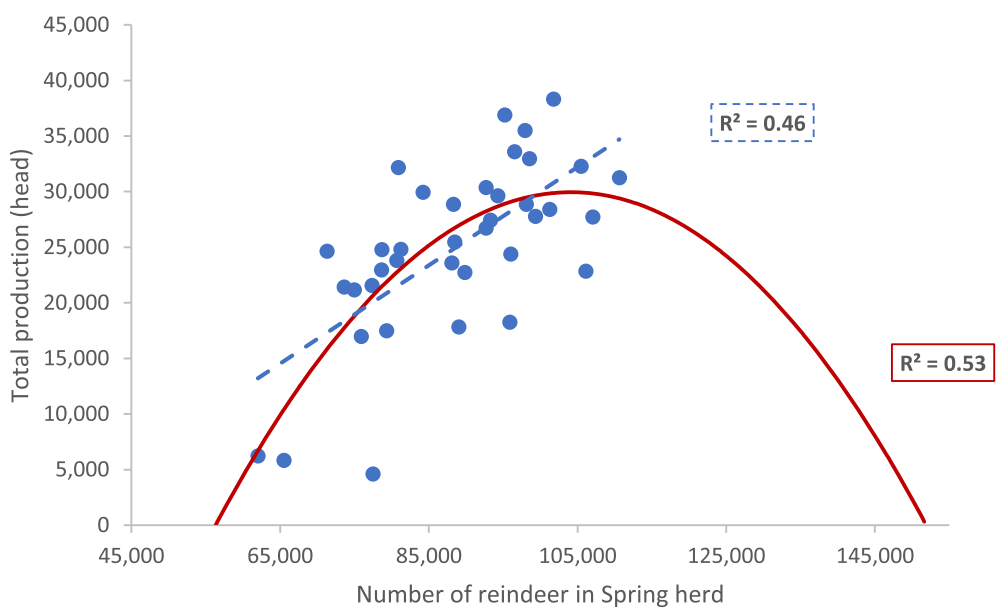

Fig. 3 Productivity in Western Finnmark, for the period 1981-2018, expressed as the relationship (linear in blue; polynomial in red) between the number of reindeer in the spring herd and total production (as head count) (data source: MAF)

is seen as driven by density-independent factors (rainfall, snow depth, temperature variations, etc.).

Again, however, the most obvious feature of the figure is the absence of any match between the locus of data points and the polynomic, equilibrium-based curve. Virtually, all of the data points are at or below the herd size corresponding to MSY; there is nothing in the data to suggest the relevance of such a specification. So, there is a necessary discussion regarding the application of these principles in practice. Unfortunately, this discussion including the caveats and limitations of the model's assumptions is often lacking from policy-making and public debates, although it is present in ecological studies (e.g. Bårdsen and Tveraa 2012).

\section{The relationship between carcass weight and density}

In Norway, based on a literal interpretation of the Røros model, a dominant focus on carcass weights has emerged as the most important indicator for the health of the interaction between reindeer and the pasture resources they use. In June 2000, the Norwegian Parliament requested the government to set the highest number of reindeer allowed for each herding district (reinbeitedistrikt). This assignment was transferred by the government to the Reindeer Herding Administration (RHA) office in Alta.

In their report (Ims and Kosmo 2001), the RHA decided to estimate the highest numbers of reindeer for each district on the summer pastures, which are defined land units belonging to individual districts, while the autumn, spring, and winter pastures are shared communally among many districts (although see Marin and Bjørklund 2015, 2016 for problems regarding the 'commons' status). These estimates were based on a regression analysis of the relationship between carcass weights of varit (1.5-year-old bucks) and the density of herds, as developed by Lenvik (Lenvik 1990; Lenvik et al. 1988; Lenvik et al. 1982). The report by Ims and Kosmo (2001) is based on data collected over a 3-year period (1998-2001) on carcass weights and densities on the summer pastures in Western Finnmark and Karasjok areas.

Ims and Kosmo (2001) found that $70 \%$ of the variation in the carcass weights of the varit could be explained by the variation in densities of the herds on the summer pastures (Fig. 4). The remaining 30\% of the variation was attributed to the influence of climate and different working conditions.

Given the small number of observations used by Ims and Kosmo (2001), we were interested to test if a higher number of observations (more years and more carcass weights in each year) would influence the analysis. We expanded our analysis to the period 1980-2012 and included ca. 57,000 individual carcass weights for varit and ca. 230,000 individual carcass weights for calves. In our analysis, we were also interested to check if there was any difference in the tested relationship in different kinds of districts (so-called mainland districts and island districts-those on islands and peninsulas). The reason for this distinction was because the density on island districts is known to be lower than that on mainland districts.

Our density calculations are based on the same surface areas used by Ims and Kosmo (2001) and the official records from the Reindeer Herding Administration that show no changes in the areas available to the districts. Whether the assumption of no change in the area available to the reindeer as pastures holds or not can, however, be debated. Jernsletten and Klokov (2002) estimated that infrastructure development, hydropower, 


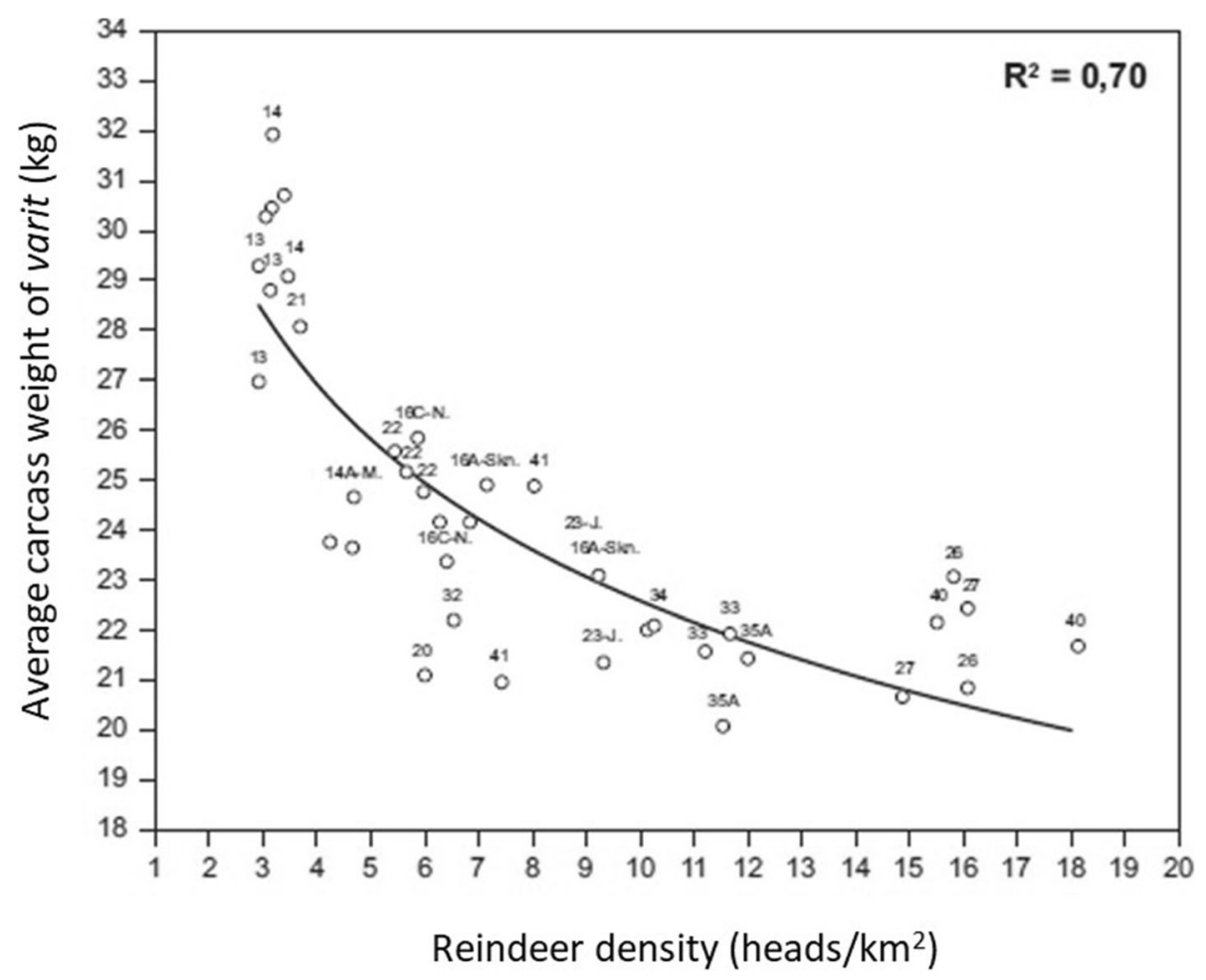

Fig. 4 Relationship between carcass weights of varit and herd density in mainland districts according to Ims and Kosmo (2001)

mining, and recreation activities had caused a $25 \%$ loss of reindeer pasture area in the region during the last 50 years, while Vistnes et al. (2004) estimated this loss to be $30 \%$. If anything, this trend of loss of pastureland to other land uses has continued since the early 2000s, even though accurate data on this trend are not readily available. In fact, the Reindeer Herding Administration has estimated (Reindriftsforvaltningen 2010) that in Norway this trend continues at a rate of $300 \mathrm{~km}^{2} /$ year, which is equivalent to more than $1 \%$ of the total area used for reindeer herding in Western Finnmark being lost yearly.

Equally problematic is also the official distinction between productive grazing areas and large areas defined as unproductive ('impediment'). Although the latter category is routinely excluded from calculations of density, herders regard at least some of these areas as important grazing resources (Sara 2001; Paine 1994). For example, herders argue that lichens that grow on old trees (Sámi: lahppu) or on stones (Sámi: gatna) are a decisive factor for the energy and survival of reindeer during late winter and early spring respectively, in years with deep or dense snow, when digging for browse is difficult. This is a strategy also recently reported by Forbes et al. (2020) for herds in Finnmark and northern Finland.

Our analysis ignored these inherent problems in order to recreate and mirror the analysis by Ims and Kosmo (2001). Our results are presented in Figs. 5 and 6 below.
The figures describe the relationship between animal density and carcass weights for varit in mainland and island districts respectively. For mainland districts, we illustrate both a linear and a logarithmic regression line (Fig. 5). The logarithmic line is similar to the one found by Ims and Kosmo (2001), but only $24 \%$ of the variation in carcass weights was explained by the variation in densities in these districts. Which is considerably less than the $70 \%$ identified by Ims and Kosmo (2001). The value for the corresponding analysis for calf carcass weights was a mere $16 \%\left(R^{2}=0.16\right)$.

When it comes to the island districts (Fig. 6), with low reindeer densities, we found no significant relationship between density and carcass weights.

While Figs. 4, 5, and 6 employ entire areas as the unit of analysis, it is worth noting that in our analysis only five districts (of a total of 25) show a statistically significant relationship between density and carcass weights. In three of these, the relationship was positive, meaning, the more animals there were per unit of territory, the heavier are the slaughtered animals (varit), or the higher the density, the higher the carcass weight. One theoretical explanation for this could be that the densities where this happens were lower than normal, but this is not the case: this relation seemed to hold for densities between 4 and 19 reindeer $/ \mathrm{km}^{2}$, whereas in the other two districts, negative relations were statistically significant at densities of 4-14 reindeer $/ \mathrm{km}^{2}$. 


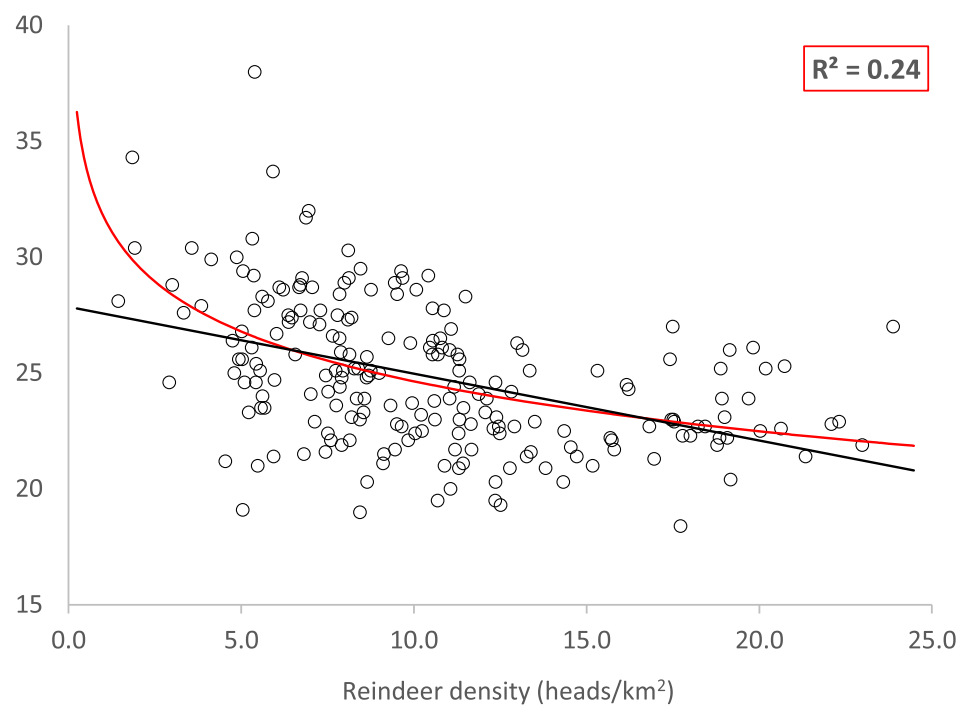

Fig. 5 Relationship between carcass weights of varit and herd density in mainland districts of Western Finnmark (data source: MAF)

Practical insight from pastoralists points however to the difficulties of determining densities in the first place and therefore to the inadequacy of density at large spatio-temporal scales as a meaningful predictor. For example, some of the districts with high slaughter weights may transport their luovvasat ${ }^{8}$ to the coast, while the rest of the herds continue grazing on calving grounds until midsummer (24 June). This would allow the young bucks to graze at lower densities and get fatter before slaughter, but it also shows that the total value for density for a district can mask very different densities that may influence different categories of reindeer differently-the densities for luovvasat can be quite high at times, given their pronounced territoriality.

The conclusions Ims and Kosmo (2001) came to must also be seen in light of the fact that they used data from 1998 to 2001. This was a particularly bad period for reindeer husbandry in Finnmark following the exceptionally bad winter of 1997, and which resulted in small (lightweight) varit the following year. In addition, the winter of 1999-2000 was also rather bad and followed by a tough spring, when much wet heavy snow came right before the spring movement toward the calving grounds and the summer pastures, in April 2000.

\section{Large-scale climate influences}

The potential influence of climate on carcass weights, or on the population dynamics more generally, is nevertheless an element that is downplayed in Ims and Kosmo

\footnotetext{
${ }^{8}$ Luovas (plural luovvasat, Sámi) is a group of male reindeer within a herd, led by mature bucks (older than 3 years) and comprising young males. They are more territorial than females and graze in areas with infrastructure and/or hilly areas.
}

(2001), but emphasized by herders, who insist that weather decides much more of the dynamics in the system, than density or total numbers do, an argument well documented by previous research (e.g. Paine 1994; Sara 2001).

There is an increasing number of investigations about the role of climate in regulating populations of reindeer across the world. Helle and Kojola (2008) indicate that $53 \%$ of the annual variation in reproduction success among herds in northern Finland could be explained by snow depth and icing. They reviewed the dynamics of seven sub-populations of domesticated reindeer in Norway, Sweden, and Finland. They concluded that an increase in snow-rich winters since 1990 has contributed to reducing population numbers in most subpopulations and that in fact, for Western Finnmark, the number of reindeer correlated significantly $(r=-0.402$, $P<0.01)$ and negatively with the North Atlantic Oscillation (NAO) during 1960-2000 (Helle and Kojola (2006).

Our analysis of the influence of climate on reindeer population dynamics revealed several interesting relations. Similar to Helle and Kojola (2006), we found a statistically significant negative correlation between the winter NAO index (for DJFM) and the changes in the numbers of reindeer in Western Finnmark: a higher NAO was related to a decrease in the numbers during 1980-2018 $(r=-0.362, P<0.05)$.

Moreover, the herds that spend summer on islands may be ${ }^{9}$ affected more by NAO. The correlations between monthly values of the NAO index and carcass

\footnotetext{
${ }^{9}$ This insight seems to contradict the accepted insight that heavier animals are generally less sensitive to difficult weather (e.g. Loison et al. 1999; Mysterud et al. 2001; Hone and Clutton-Brock 2007) and would therefore need more detailed future investigations.
} 


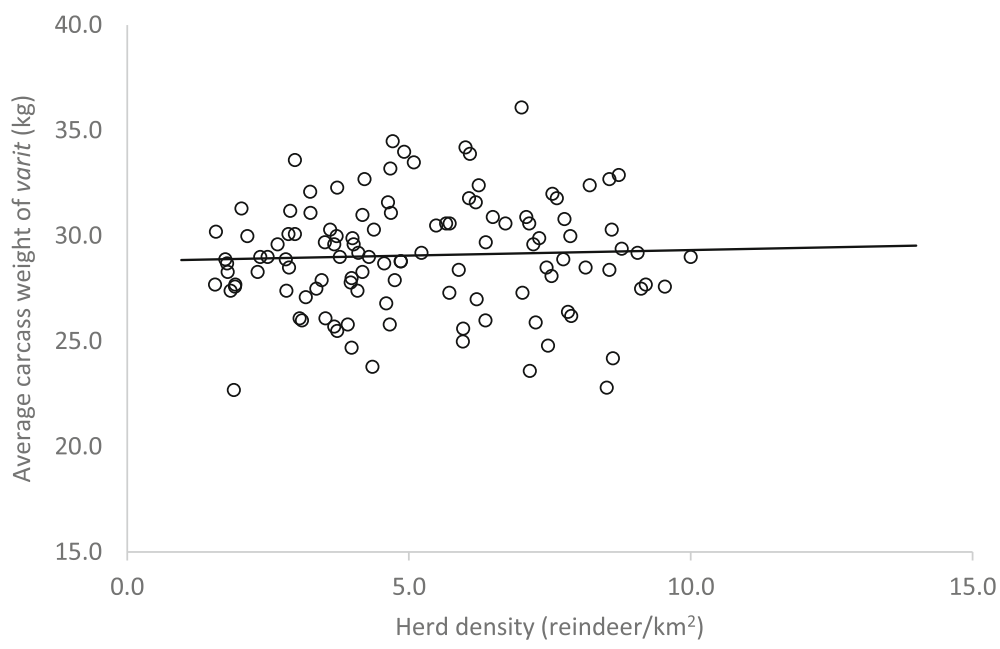

Fig. 6 Relationship between carcass weights of varit and herd density in island districts of Western Finnmark (data source: MAF)

weights of calves in the interval 1961-2014, although weak, were statistically significant $(P<0.05)$ for December and February ( $r=-0.146$ and $r=-0.119$ respectively), and the correlations seemed stronger for herds that spend summer on islands and peninsulas $(r=-0.2065$ and $r=-0.2268$ respectively). For carcass weights of varit (1.5-year-old bucks), there were similar results: they were correlated $(P<0.05)$ to winter NAO $(r=-0.1331)$ and NAO in December $(r=-$ $0.1305)$, but the relation seemed stronger for carcass weights of varit from island and peninsulas $(P<0.01, r=-$ 0.2391 and $r=-0.2448$ respectively). Although statistically weak, the distinction between the general relationship and the one for groups on island and peninsulas alludes to the explanation that the herders themselves proposed: that the herds accustomed to good grazing (and low densities) on the islands/peninsulas tend to suffer more during bad winters, characterized by high NAO.

This is an insight that has been mentioned by reindeer herders historically. Nielsen and Ulve (2018) cite interviews from 1911 where Sámi reindeer herders in Finland give detailed accounts of how reindeer accustomed to very good pastures become emaciated on leaner pastures, although reindeer used to these leaner pastures are 'fat and fair' (p. 255, 289). Currently, herders in Finnmark seem to reiterate this in observations that reindeer accustomed to fodder (hay and/or concentrate) lose weight very fast when released in herds that graze on natural vegetation. Although there are to our knowledge no studies about the mechanisms behind this phenomenon in Fennoscandia, other pastoralists (Marin 2010) seem to confirm a similar situation, which has been explained as being the effect of a combination of foraging skills (selecting only high-quality habitats), digestive system development, and gut-microflora in turn related to particular feeding history and exposure to a certain array of plants (Provenza and Balph 1987; Stamps and Swaisgood 2007).

However, although regional climate (approximated by indices such as NAO) exerts effects on local weather and in turn on population dynamics of reindeer and other ungulates (e.g. Post and Forchhammer 2002; Weladji et al. 2002), this influence can be masked by local conditions and management decisions (Uboni et al. 2016). The largescale climate proxies (like NAO) merely give an approximation of the enormous range of local micro-climates and micro-relief, complicating conclusions about possible density-independent mechanisms (Tyler 2010).

\section{Weather influences}

Following Ims and Kosmo (2001) who focused on mainland areas, we performed a multivariate regression that included local climatic variables (growing degree days and precipitation) as predictors of carcass weights of calves and varit from mainland districts (Table 1, see also suplementary material). The weather stations used in the analysis in Ims and Kosmo (2001) were not stated in the report. However, we used the data from three stations that are most relevant for the climate affecting summer districts. We investigated the role of two variables: total precipitation (computed by adding up all the daily observations for a given period of time) and growing degree days ${ }^{10}$ (GDD) (computed as the sum of the positive difference between daily mean temperature and a chosen base temperature for a period of time). The period when the temperature is above $6{ }^{\circ} \mathrm{C}$ is considered the summer grazing period (Ims and Kosmo 2001), so we also used $6{ }^{\circ} \mathrm{C}$ as the base temperature for our analyses (Table 1).

\footnotetext{
${ }^{10}$ Growing degree days is a measure of heat accumulation.
} 
Table 1 Ordinary least squares (OLS) multiple linear regressions of varit and calf carcass weights for mainland districts

\begin{tabular}{|c|c|c|c|c|c|c|}
\hline & \multicolumn{3}{|l|}{ Calf } & \multicolumn{3}{|l|}{ Varit } \\
\hline & $E$ & SE & $P$ & $E$ & SE & $P$ \\
\hline Intercept & 18.5290169 & 0.8199378 & $<2 \mathrm{e}-16^{* * *}$ & 25.344684 & 1.866067 & $<2 \mathrm{e}-16^{* * *}$ \\
\hline Density & -0.1588639 & 0.0191705 & $4.01 e-15^{* * *}$ & -0.320338 & 0.036857 & $3.77 e-15^{* * *}$ \\
\hline GDD May & 0.0308272 & 0.0063496 & $1.95 e-06^{* * *}$ & 0.019079 & 0.012322 & 0.12348 \\
\hline GDD June & -0.0079061 & 0.0037241 & $0.0346 *$ & -0.020019 & 0.006879 & $0.00412^{* *}$ \\
\hline GDD July & 0.0034387 & 0.0026601 & 0.1971 & -0.002109 & 0.005337 & 0.69331 \\
\hline GDD Aug & -0.0004823 & 0.0028245 & 0.8645 & 0.010229 & 0.004932 & $0.03965^{*}$ \\
\hline Precip. May & 0.0010688 & 0.0098873 & 0.9140 & 0.047782 & 0.017530 & $0.00712^{* *}$ \\
\hline Precip. June & -0.0374231 & 0.0060198 & $1.71 \mathrm{e}-09^{* * *}$ & -0.053464 & 0.009845 & $2.02 \mathrm{e}-07^{* * *}$ \\
\hline Precip. July & 0.0191154 & 0.0044997 & $2.88 \mathrm{e}-05^{* * *}$ & 0.035462 & 0.007439 & $4.13 e-06^{* * *}$ \\
\hline \multirow[t]{2}{*}{ Precip. Aug } & -0.0010057 & 0.0036399 & 0.7825 & 0.032193 & 0.007470 & $2.83 e-05^{* * *}$ \\
\hline & \multicolumn{3}{|l|}{$\begin{array}{l}R^{2}=0.2988 \\
N=314\end{array}$} & \multicolumn{3}{|l|}{$\begin{array}{l}R^{2}=0.4928 \\
N=178\end{array}$} \\
\hline
\end{tabular}

Significance levels: ${ }^{*}<0.05 ;{ }^{* *}<0.01 ;{ }^{* * *}<0.001$. (Data source: Norwegian Meteorological Institute)

Our results show statistically significant effects of precipitation and temperature for the carcass weights of calves (positive for GDD in May and precipitation in July and negative for precipitation in June) and varit (positive for precipitation in May and July and negative for GDD and precipitation in June).

Nevertheless, the effects of climate can only be interpreted at the small spatial and temporal scales and in connection with herd dynamics and accessibility of appropriate seasonal grazing. The timing of weather events seems to be as important as their presence. Live weights of 4-month-old calves have been shown to be influenced by both the amount and the timing of snow during their mother's pregnancy (Hendrichsen and Tyler 2014). Much snow at the end of winter predicted low calf weight and vice versa, irrespective of the amounts of snow in the beginning of the season.

Despite the staunch trust in the explanatory power of density dependence, climatic conditions thus appear to play a very important role in the dynamics of the reindeerpasture systems. Tyler (2010) makes this point abundantly clear in his review of 31 declining events among 12 circumpolar reindeer populations, concluding that:

In all cases, the observed dynamics are best interpreted as a product of interaction between internal processes (density dependence) and the external abiotic conditions (density independence). The strength and the form of density independence, parameterized in terms of local weather or large-scale climate, varies widely between populations, reflecting the enormous range of climate conditions across the circumpolar distribution of Rangifer. This complicates the search for abiotic components likely to be consistently important determinants of population growth in the species (p. 197).
The evidence we present above leads us to the conclusion that models like the Røros model, with their overemphasis on herd size and density, are too simplistic to be able to reflect a rather complicated reality. This is of course 'old news' for studies of pastoral systems in the drylands of Asia and Africa, where a wholesale paradigm shift from equilibrium to non-equilibrium modelling took place from the early 1990s. The new paradigm emphasized that often climate variables are more important in shaping system dynamics than animal density and reproductive success (Ellis and Swift 1988; Behnke et al. 1993; Scoones 1995; Sayre 2017). These new ecological ideas have also been proposed as relevant to sub-arctic systems (Tyler 1998; Behnke 2000; Marin 2006; Holand et al. 2010; Benjaminsen et al. 2015; Reinert and Benjaminsen 2015).

Still, like in many other pastoralist systems of the world, the attraction of simple explanations and simple models remains strong. This simplification tends to over-emphasize biological knowledge and concerns, while little attention is being paid to social circumstances and to the knowledge of the reindeer herders themselves (Benjaminsen et al. 2016a). We now turn to empirical evidence provided by herders in Finnmark in order to illustrate important elements that are missing in a management system guided chiefly by densitydependent thinking.

\section{Pastoralist strategies and their relation to the Røros model}

The density-dependence model has resulted in a series of recommendations and incentives that reward herders who keep herd structures based on high proportions of young does, slaughter calves, and reduce the number of 'unproductive' animals (bucks, castrates, older does). 
Importantly, the system rewards herders who agree to keep low densities of animals on the pastures. This section examines the central assumptions of the model and the logic it entails in light of empirical evidence based on the practices of reindeer herders and relevant scientific evidence from across Fennoscandia.

In general, it is safe to conclude that herders in Finnmark have varied attitudes and approaches to the state provisions and herding more generally. However, what at a first glance may look like an acceptance of the model's assumptions is in fact a circumstantial compliance that suits the situation a herder or group find themselves in at any given time (Benjaminsen et al. 2016b; Marin 2006).

Reindeer herders are often opposed to slaughtering calves for cultural and practical reasons. On the practical side, calf meat is not in demand on the private market, whereas buck meat is the most sought-after produce. The private meat market (including own consumption) in Finnmark, where consumers buy directly from the herders, is estimated at $22 \%$ of all slaughtered animals in Western Finnmark respectively (Reindriftsforvaltningen 2013). Moreover, based on our research and practical herding experience, herders slaughter mostly older animals for own consumption, very seldom calves. Calves were traditionally slaughtered for skin products and then early in August. Leaner bucks and does are better suited for curing and for boiling the meat, whereas fatter animals are better suited for dried meat (Skum et al. 2016).

It becomes apparent therefore that when the only production goal is the maximization of carcass weights, leaner (and lighter) animals are not valued, despite their qualities that are valuable for particular products. There is clearly a gap between the products pushed for by the management system, focused on subsidies for calf slaughter, and the types of products that the herders produce for the private market.

Another important issue emerging from the standardization of production is the reduced access to by-products from the slaughtering of reindeer. This problem is granted little attention in the political debate, yet it has serious implications for the reindeer herding communities. The traditional Sámi handicrafts (duodji) is based on such by-products. Herders must now pay the abattoirs in order to recover the skins and bones from their own animals, and during the slaughtering, many skins are destroyed by cuts. This is the reason why the raw material for duodji derives mostly from privately slaughtered animals. This also limits access to goodquality skins that can be used for example in producing reindeer skin boots (Sámi: nuvttohat; goikkehat).

Despite all these disadvantages, some herders do follow the recommendation of the Røros model. Still, the reasons for doing so are often complex.
For instance, one herder, who has his summer grazing area on an island, practises calf slaughtering because he faces difficulties transferring from good summer pastures on the island to marginal autumn pastures on the mainland. The calves are then slaughtered in the first autumn of their lives, not the second, which would have been more profitable. The motivation is nevertheless not the wholesale acceptance of the need for low animal densities, but rather that the animals get used to good grazing conditions on the islands during summer and therefore are less tolerant of the poorer pastures in autumn and winter (Benjaminsen et al. 2016b).

Other herders, who apparently have complied with the low densities and herd structure recommended by the state, explain that they have done so because their grazing rights have been encroached upon by other, bigger, herds. So, in order to avoid potentially disastrous economic losses (when their unmarked animals disappear into the larger neighbouring herds), they prefer a smaller herd, controlled tightly and sometimes fed supplementary fodder. Still, detailed accounts of such strategies also illustrate that decisions are taken in a complex of circumstances that also include the threat of an increasingly unpredictable climate and the very visible threat of forced slaughtering by the state (Benjaminsen et al. 2016b).

\section{The role of bucks in the Røros model}

Conversely, if one does not respect the herd structure recommended by the Røros model, this does not mean that the herder is not considering it as a possibility. It simply reflects that the herding and husbandry context in which that particular herder operates does not fit the model.

The model is premised on the idea that bucks have one role only: reproduction. Lenvik (1990: 31) mentions for instance that '(...) male animals that are redundant from a mating point of view, take over pasture that could alternatively be used for does'. Most herders have a rather different view on the role of bucks. They point out that bucks have many different roles in a herd. One of these is that bucks improve the herd's use of pastures by grazing on areas not used by other reindeer in the herd. For instance, one herder who resists the government policy does not slaughter calves and keeps a higher proportion of males. He does not reason in terms of density at all, but is motivated by the types of grazing areas he has access to. Because his pastures are close to infrastructure (roads, buildings, power lines), which is usually avoided by female deer and calves, he needs to keep more bucks to be able to use what he calls 'buck pastures' (Benjaminsen et al. 2016b).

Another similar example is a herder with summer pasture close to a highway. These pastures are not grazed 
by does and calves, but his bucks are much less wary of this disturbance and use these pastures, as well as pastures in the proximity of settlements and other infrastructure. This particular herder has large areas that can be defined as 'buck pastures'. If he reduced the percentage of bucks in his herd to fit the model, he would not be able to use these pastures (Benjaminsen et al. 2016b).

Generally, only bucks can use steep and rough terrain, especially during the calving period. The bucks, and especially the castrated ones, are also much stronger and thus manage to dig through snow and ice to get to the pastures below. In east Siberia, castrates are also valued for their ability to calm down the herd and as indispensable for digging during 'black ice' events that lock pastures under ice (Magga et al. 2009, p. 37). In Finnmark, castrates are useful because they more readily share the craters they dig in deep snow and make pastures accessible to the rest of the herd. Castrates also retain good weight throughout the year, in part because they do not go into rut, thus being a reliable source of meat. In addition, a large proportion of bucks also contributes to calming the herd down (thus reducing herding effort), avoiding dispersals of the herd triggered by the predators' presence (see Skum et al. 2016 for a review of the role of bucks).

To have a relatively high percentage of bucks in one's herd is therefore beneficial for many reasons, but there are hardly any herds in Finnmark nowadays with more than $10 \%$ bucks (Skum et al. 2016).

These insights suggest that, rather than reducing the number of bucks further, there may be an increasing role for bucks given the rapid expansion of infrastructure and other anthropogenic disturbances in Finnmark. Still, the pastures in Finnmark are never classified in relation to their suitability to different categories of animals. Moreover, the concept of 'buck pasture' is virtually non-existent in the scientific literature on reindeer herding. Instead, we have an ideal-typical and averaged relationship between animals and pastures, hinged on the role of the density of 'average reindeer' over 'total area'. This is not meaningful for reindeer herders and makes their logic incommensurable with the density-driven arguments.

\section{Feeding the reindeer}

Pastoralists in Africa and Asia employ various strategies in the face of climatic change and its impacts. Some may choose to buffer against unpredictability by diversifying their sources of income (through involvement in trading, agriculture, or seasonal labour). State interventions have also contributed to buffering by providing insurance schemes, livestock banks, or stable marketing schemes (Behnke and Kerven 1994; Scoones 1995; Sandford 1995).
On the other hand, herders may also track environmental variability by adjusting their number of animals (pre-emptively or reactively) or by moving their livestock to where resources are located. In stressful periods (e.g. droughts), a significant proportion of the herds may be slaughtered and sold in the hope that the reduced pastoral resources would ensure the survival of the remaining herds and that the income from the sales would allow herders to restock and rebuild their herds during good periods (Behnke and Kerven 1994). In Sámi reindeer husbandry, the amount of castrated and semicastrated bucks has also had an effect on herd demography (Skum et al. 2016).

Similarly, in Finnmark, during crisis situations, which the Sámi herders call goavvi (e.g. difficult winters with unusual amounts of snow or icing that 'lock' pastures and make them inaccessible), there are two solutions to keeping the herd alive. One is to feed the herd with hay, pellets, or harvested lichens, while the more traditional one is to move the animals away from the difficult area and into reserve pasture areas with more easily accessible pastures (Eira 2012). Due to the loss of pastureland and increased pressure on the existing pastures, reserve pasture areas have become less available. This is one important reason why additional feeding of reindeer has become more commonplace in recent years. So much so, that it is now also being used during normal conditions. Herders that employ the Røros model seem to be more likely to also use additional feeding and regard this as necessary for ensuring production and hindering the herd from spreading and mixing with other herds, in their search for pastures (Benjaminsen et al. 2016b). One consequence of this practice is that the food requirements of the animals increase, and thus, they will dig and eat more than they would had they not grown accustomed to additional feeding (Holand 2003). To feed a herd under normal conditions is very labour-intensive and perhaps not very profitable. Still, the economic benefit depends on the size of the herd. A large herd would be more cost-ineffective to feed (Holand 2003).

Although herders accept feeding during goavvi, they are much more critical about feeding during normal years. Most of the herders we have interviewed, who do not use the Røros model, point out that the reindeer should be able to make do with what is available, not rely on feeding. This is a common attitude among many Sámi herders. Many have ethical misgivings toward making reindeer dependent on humans for food, since the ideal image of the reindeer is of a free, mobile, and independent animal.

Additional feeding can lead to behavioural changes among reindeer and thus influence the grazing dynamics within the herd. The animals can lose some of their abilities to find suitable pastures on their own. More feeding 
can actually lead to less grazing. If the feeding is regular, the animals stay closer to the feeding sites, they can follow the snowmobile tracks, and when they smell hay, they run in the direction of the scent.

Some herders argue that after one has started feeding the animals, it is hard to stop because the animals become more dependent on humans. Instead, one would want a herd that is resilient and independent so that it can survive winter on its own. One can achieve this by not feeding the animals and by keeping a varied herd structure.

\section{An alternative way to measure productivity}

So far, we have not questioned one of the most central assumptions of the Røros model: that carcass weights provide a good measure of productivity. To the extent that the herders want to increase productivity, they are more likely interested in increasing the productivity of the herd per unit of land, rather than per individual animal (i.e. having few and heavy animals). There is some evidence that herders would accumulate reindeer as a mitigating strategy against unpredictability and risk (Næss and Bårdsen 2010, 2013). More generally, insurance incentives may be particularly strong when longterm herd viability is linked to size thresholds (Lybbert et al. 2004). Conversely, pastoralists in arid and semiarid areas sometimes survive drought cycles by destocking, but this is a complicated decision that has been successful only in very specific circumstances (e.g. Morton and Barton 2002). More often, pastoralists in these areas aim at reducing the number and magnitude of their errors, rather than reducing their herds (e.g. Roe et al. 1998). Similarly, in Finnmark, destocking does not seem to be used as a strategy to deal with bad weather. Instead, the logic of herders here seems to be that reindeer will inevitably lose weight and fitness during winter, some (e.g. calves) more than others (e.g. calfless does), and even die. However, it is preferable (and more productive), herders would argue, to have two reindeer that make it to spring in worse condition, than only one that makes it in excellent condition.

One alternative way of measuring productivity would be to measure the volume of meat produced per square kilometre in a year. While still not reflecting the complex strategies of the herders, this way of measuring productivity is better suited to the pastoralist logic. While reflecting the herders' orientation toward economic profit (they have to sell meat to run their operations), this measure also includes other decisions about the herd productivity, like culling of weaker animals. Whereas the Røros model implies that low carcass weights reflect bad conditions in the system, it cannot ignore the fact that the sample of slaughtered animals does not necessarily reflect the weights of the entire population.
Herders may be choosing to slaughter either heavier or lighter animals depending on a large number of circumstances. They typically slaughter reindeer (calves and adults) in normal condition for the autumn delivery to slaughterhouses. When it comes to calves and older females, the owner will try to keep the animals that are judged as best according to a thorough evaluation that in addition to weight includes sex, character, grazing behaviour, among other circumstances. Moreover, during winter, herders select for own consumption and for supplying other local buyers with the fattest reindeer, due to cultural preference. Although the number of these animals is small, their carcass weight is being recorded in official statistics as equal to the average carcass weight of the normal autumn delivery to the slaughterhouses, probably underestimating the real productivity.

It is also difficult to calculate area productivity at the level of production unit (siida) because there are no clear measurements of how big an area of the common winter and spring/autumn pastures each siida uses. Still, these measurements have been done at the level of regions by the Reindeer Herding Administration.

If we compared the two regions where the management systems are most different, we would have to compare Western Finnmark and the Røros area (which consists of the counties of Hedmark and South Trøndelag in southern Norway). The Røros area is often mentioned in public debates as the prime example of the best management system for reindeer pastoralism, whereas Western Finnmark is usually presented as the area with the biggest problems.

The comparison shows that area productivity has, on average, been very similar in the two regions over a 37year period (1980-2017) (Fig. 7). These two regions are incidentally the ones with the highest productivities among all seven regions monitored by the Reindeer Herding Administration. It is worth noting that the average area productivity in Western Finnmark $(22.4 \mathrm{~kg} /$ $\left.\mathrm{km}^{2}\right)$ is slightly above the one in Røros $\left(21.8 \mathrm{~kg} / \mathrm{km}^{2}\right)$ despite the much more difficult and variable climatic conditions that one finds in Finnmark.

It is relatively standard in ecological literature to estimate MSY as productivity either per unit area or per animal, and the first approach has been proposed for Norwegian wild reindeer populations (Skogland 1986). In addition, in wild populations, the densities at which productivity peaked differed by $24 \%$ according to whether the goal was maximizing the number of animals (2.3 animals $/ \mathrm{km}^{2}$ ) or the biomass produced (1.75 ani$\mathrm{mals} / \mathrm{km}^{2}$ ) (Skogland 1986). Maximizing the number of animals and productivity per unit of area is nevertheless closer to the pastoralist logic for several reasons. First, pastoralists are interested in various characteristics in their animals, where weight (and the consequent good 


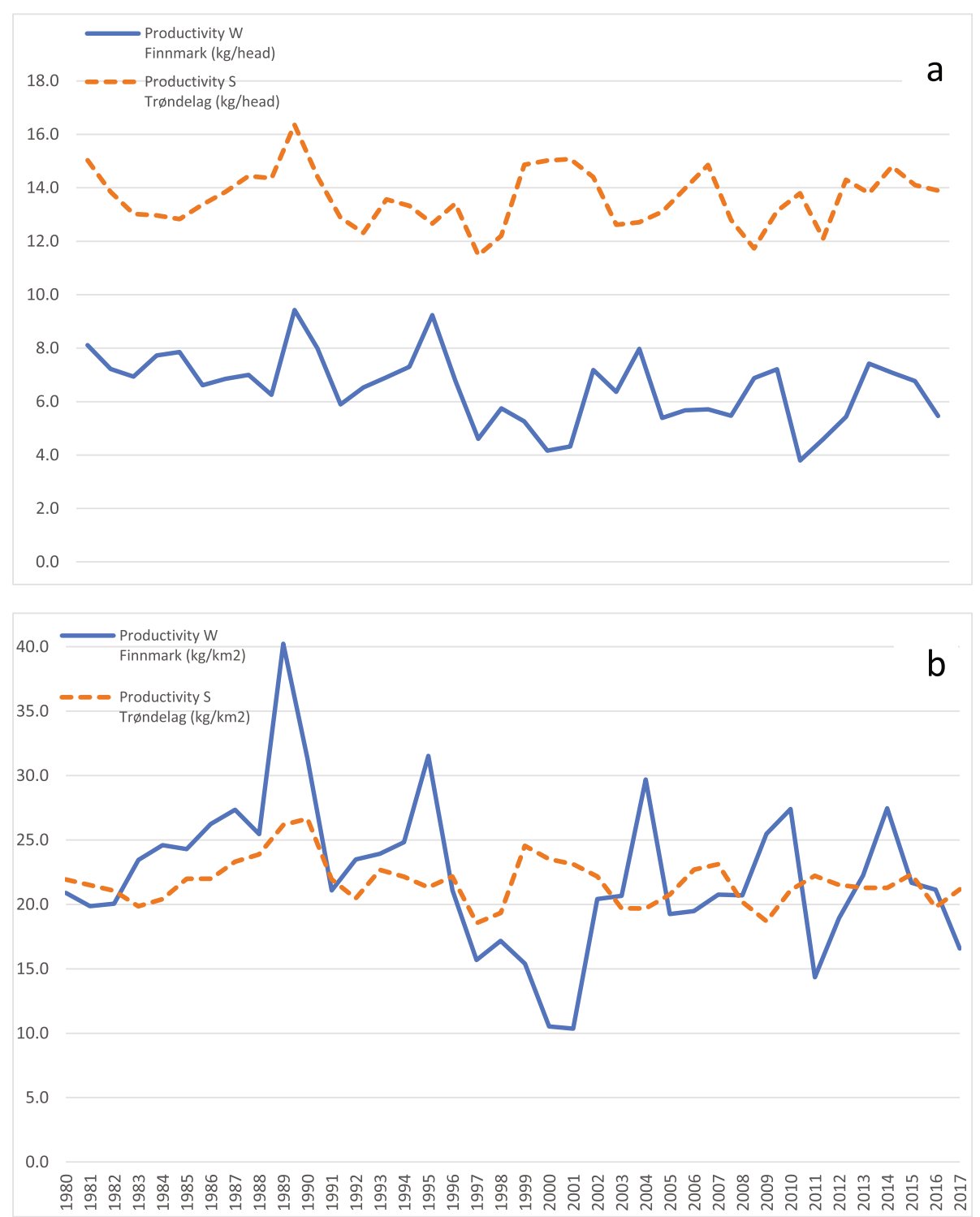

Fig. 7 a, b Productivity in the regions of Western Finnmark and South Trøndelag measured as A) kilogrammes per head of reindeer at the start of the year (1 April) and B) kilogrammes per square kilometre (data sources: MAF, Resurssregnskapet 2016/2017, 2017/2018)

market price) is one of a long list that includes docility (or lack of thereof), maternal instincts, leadership, fertility, etc. Second, area-based productivity is generally a better estimate of the balance between animals and grazing resources. For example, pastoralists of western Tibet describe thousands of named pasture areas in terms of how many marke they had. While 1 marke can be interpreted as a surface area, it was in fact an estimation of how much butter it was possible to produce from the said area, which in turn could mean that in order to produce one marke of butter, one was likely to graze the said area by 13 yaks or the equivalent in goats (7 to 1 yak) or sheep (6 to one yak) (Goldstein and Beall 1990,
1991). The principle was that the actual size of the pasture was irrelevant; it was how much could be produced from it that formed the basis for assessing its quality (and how much the pastoralists using the respective pasture were taxed). Although this estimate can seem similar to a carrying capacity estimation, it was in fact based on a non-equilibrium thinking, where the marke was constantly reevaluated. The pasture areas were reallocated every 3 years to different households. Within each nomadic sub-group, households were moved from one sub-group to another, or even entire sub-groups swapped pastures between them. Helle and Kojola (2006) make precisely this point for reindeer pastoralism: 
whereas for management authorities carrying capacity is useful as a fixed point on the curve describing the relationship between grazing resources and reindeer meat production, for herders, carrying capacity makes sense only if treated as variable. In this sense, although maximum lichen biomass can vary between 1500 and 2800 $\mathrm{kg} / \mathrm{ha}$ in Finland, the reindeer 'can fulfill their requirement in normal snow conditions with a lichen biomass of about $350-500 \mathrm{~kg} / \mathrm{ha}$ ' (p. 335). It is therefore unrealistic to think that one can estimate the right fixed value for a carrying capacity at which reindeer may fulfill their requirements, if both lichen biomass and snow conditions are so variable.

Similar to their Tibetan counterparts, the Sámi herding views on numbers of reindeer in relation to grazing resources accomodate variability more readily. If we think of the Sámi households (báiki), and the siidas subgroups, their own traditional system of pasture allocation was similarly flexible, with overlapping borders, relocation of households within siidas and even between siidas. This was a similar form of flexibility allowing for adjustments between the types of herds with different compositions (more bucks, more does, etc.) and between different husbandry and herding strategies (Paine 1994, 2009) to find the right types of pastures that suited these particular strategies and social circumstances. The current formalization of land rights and allocation of particular, fixed summer pastures (and the on-going efforts of formalizing rights to autumn/spring and winter pastures) is likely the only functional option in the current system, hinged on assumptions about fixed carrying capacity. It is nevertheless a logic that relies on the assumption that all reindeer are commensurate to each other and that all pastures are essentially defined by their size. And this is something that goes against the pastoralist logic, in Finnmark, Tibet, and elsewhere.

Furthermore, alternative ecological models suggest that (sub-) arctic systems such as those of the Finnmark rangelands might reflect non-equilibrium behaviour similar to that observed in highly variable ecosystems in Africa (Behnke 2000). Concerning the relevance of a non-equilibrium model for the Arctic, Behnke (2000: p. 147) argues that in semi-arid Africa and Australia weather influences the plant/herbivore relationship in a simple way through rainfall. The situation at higher latitudes is more complex: fluctuations in both temperature and precipitation influence both the growth of forage in summer and the availability of forage in winter (Behnke 2000). Thus, one set of variables (rainfall, timing of thawing in spring, etc.) may cause fluctuations in the quantity and quality of feed production, while a second set of variables (depth of snow cover, prevalence of ground ice) determine how much of the total primary production is accessible to herbivores in winter (Post et al. 1997; Forchhammer et al. 1998). Weather-induced stress is therefore a function of the impact of individual factors, their correlation, and their additive or offsetting consequences, in other words, how this variability is 'packaged' in individual years (Behnke 2000).

The vegetation in the sub-Arctic is also differently influenced by fluctuations: green vegetation reacts rapidly to weather stimuli, while lichen responds more slowly, although recent research demonstrates that lichen growth can be faster than previously believed (Bidussi 2014). Different responses by different vegetation that is important in the reindeer diet complicate the prediction of appropriate stocking densities, as the different feeds are consumed in different periods and influence different vital rates (e.g. growth in the summer, pregnancy success, birth rates in the winter) (Sæther 1997). This thrust of research supports the arguments of the herders that climatic events and use patterns influence the growth and numbers of reindeer, justify the traditional herding strategies that acknowledge these fine distinctions, and try to meet the challenges imposed by variability.

Climate studies relevant for the population ecology of reindeer in Fennoscandia support the narratives of the herders related to the evolution of climatic parameters, showing an overall increase in precipitation, with a large between-year variability throughout the twentieth century (Yoccoz et al. 2002). The series of particularly warm and wet winters started at the end of the 1980s and continued through the 1990s in Finnmark, a period when the Røros model got increased traction. Furthermore, the variability patterns changed for the same period: while in the 1930s and 1960s the variability was annual, starting with the 1970s, it became decadal (i.e. climate trends lasted for up to 10 years). Moreover, the atmospheric circulation patterns had a homogenizing influence on the temperature patterns in winter (i.e. a warm winter is warm overall) (Yoccoz et al. 2002). This supports the claims of the herders for 'bad years' during the last decade.

The results are supported by other research in the area that show 'since the late 1980s there has been a gradual warming, with the positive temperature anomalies increasing', especially for the winter temperature (Lee et al. 2000, Kelman \& Warg Næss 2019). Others (Vikhamar-Schuler et al. 2016) have shown that in Finnmark, the number of winter days with mild weather has increased significantly (by up to 35 days), the amount of precipitation falling as wet snow is expected to increase (Tveito 2014), and events known as rain-on-snow that seem to increase in frequency and intensity in the region (Vikhamar-Schuler et al. 2016; Forbes et al. 2016). All these changes can have significant negative impacts on reindeer herding in Finnmark. Lee et al. (2000) show a strong negative effect of mild winters: the warmer the winter prior to the time calves are born, the fewer calves 
are born. The study also showed that climate change may promote the faster growing vascular plants to outcompete lichens (Lee et al. 2000). There is increasing attention to the combined effect of grazing and climate for the region: some identify an increase in precipitation as a source of possible out-competition of the lichens by the vascular plants (Crittenden 1999). Others show that the effects may be complex (Petorrelli et al. 2005) and different for birch forests (Tømmervik et al. 2009), willows (Forbes et al. 2010), or mires (Kolari et al. 2019). The effects of wet, mild, and variable winter weather may nevertheless translate in winter freeze-over of large grazing areas, events that have always been feared by reindeer pastoralists in Fennoscandia (Turi 2011 [1910], Forbes et al. 2016). However, although some of these environmental changes are becoming apparent in Finnmark, the herders' reduced ability to adapt to this climate-induced stress derives to a large extent from limits induced by misconceived governance regimes (Eira et al. 2018). Just like herders in other pastoralist systems that have to deal with winter disasters and similar freeze-overs of grazing resources (e.g. Marin 2008, 2019; Yeh et al. 2014; Robinson and Milner-Gulland 2003), the roots of the problems seem to be externallyimposed governance systems that are too rigid. Herders across latitudes seem to echo insights that have been standard fare in state-and-transition or non-equilibrium ecological models that propose an adaptive management approach (Rist et al. 2013) where the logic of the resource management should be to 'see itself as engaged in a continuing game, the object of which is to seize opportunities and to evade hazards, so far as possible. The emphasis would be on timing and flexibility rather than on establishing a fixed policy' (Westoby et al. 1989, p. 271).

Because of the conflicting views and epistemological stances of what constitutes good evidence for assessing the impact of reindeer grazing on vegetation, some have proposed a standardized protocol for such assessments in Fennoscandian reindeer pastoralist systems (Bernes et al. 2015). This protocol incorporates the knowledge of Swedish stakeholders with an interest in reindeer husbandry, ranging from environmental protection agencies, Ministry of Rural Development and scientists, to the Sámi Parliament. Importantly, the stakeholders pointed out that 'overgrazing' was a questionable concept, not to be included in the protocol. Instead, the impacts of reindeer herbivory (including grazing, browsing, and trampling) should be assessed by investigating changes in vegetation that refer to cover (abundance), biomass, diversity (e.g. species richness), structure, compositions (at species and functional groups), and productivity (Bernes et al. 2015, p. 4). However, the authors of the protocol underline the importance of monitoring the heterogeneity of reindeer herbivory effects and propose (based on earlier empirical evidence and theoretical models) that a long list of factors can modify the effect of grazing, such as latitude/longitude, elevation, local climate (and climate change), vegetation quality (e.g. nutrient content), grazing history of the site, husbandry methods (e.g. use of supplementary feeding), and the presence of human activity or infrastructure (e.g. fences). At the same time, they identify the lack of actual measurements/quantification of reindeer density as reducing the quality of the assessments and increasing their susceptibility to bias (Bernes et al. 2015). The assessments in Finnmark nevertheless are often characterized by this bias, estimating the density simply as 'heavy/medium/no grazing' but are seldom based on actual measurements of numbers of reindeer observed to be grazing on particular areas at any given time. It becomes evident therefore that contextual and complex calculations inherent in the pastoralists' logic are at odds with the simplified and rigid model espoused in the currently dominant management model.

\section{Conclusion}

The Røros model holds a central place in the Norwegian management system framing reindeer pastoralism in Finnmark and reflects an increasing pressure to modernize and rationalize production in the Sámi reindeer pastoralist system (Johnsen and Benjaminsen 2017). The model hinges on classic ecological equilibrium models where there is a clear unequivocal relationship between animal densities, production, and carcass weights. The central idea of the model is that herders should produce calves for slaughter based on a high percentage of young does and very few bucks kept for reproduction purposes. Based on the data from the period 1998-2000, the theoretical model was proposed as relevant to the reindeer pastoralist system since, it was claimed, most of the variation in carcass weights (and by implication, the sustainability and productivity of the system) were a result of animal density (Ims and Kosmo 2001). These conclusions have had enormous influence in the current management regulations imposed by the state. Our analysis investigated these conclusions first by expanding the empirical material to include a longer time perspective. We found that only a limited portion of the variation in carcass weights can be attributed to variations in the animal densities, suggesting that environmental circumstances such as long-term climate and weather variability play a much more important role in determining carcass weights than earlier assumed. This is also in agreement with the knowledge the reindeer herders themselves present and for which they have argued for a long time.

Some of the herders in Finnmark do follow the subscribed model. However, in order to understand why 
these particular herders found the model possible to use and under which circumstances, we have to draw on a more detailed contextual understanding of opportunities and constraints in which they operate. Some do not follow the model because they are concerned with the importance of bucks on the winter pastures and thus keep a different herd structure than that recommended by the density-driven model. Even so, these herders may still slaughter calves if they experience losing unusually many calves during winter due to poor winter pastures. Choosing to slaughter during autumn means avoiding high mortality on the winter pastures, rather than a belief in the importance of low densities.

Others have apparently accepted the model and the assumption that calf slaughtering is economically profitable, but did so mainly in anticipation of the planned forced slaughter that the authorities for several years threatened to carry out and have recently started. Others still choose a similar strategy because they were able to fence off winter pastures, reduce their herds and start slaughtering calves, and receive state subsidies rewarding their compliance with the management model.

For the vast majority of herders, it appears that a fully fledged restructuring toward the Røros model of production is meaningless, whereas only a small minority can follow the model's provisions to varying degrees. Local geographical variations seem to have a strong influence on the applicability of the model. The bucks use areas that other types of reindeer avoid. With more extreme and unpredictable weather brought by climate change, and documented many places in the Eurasian sub-Arctic (Forbes et al. 2016; Callaghan et al. 2011), the bucks become important assets that can make winter pastures accessible to weaker animals during winters with much snow or icing. These circumstances are not taken into consideration by the model. This is why doe herds with many calves and few bucks would be exceptionally exposed during bad years. Bucks and castrates would also mitigate attacks from predators and dig through difficult ice and snow.

Today, the Røros model's main elements (that production is density dependent; that herds should be based on does, with a minimum of bucks; and that there is a strong relationship between density and carcass weights over the whole of Finnmark) still dominate in the current policy formulation in Norway. We argue however that the model may be incorrect in a variety of circumstances and that it can therefore not be used to frame important governance policies. We also critically reflect on the model's productivity goal. We suggest that productivity per area unit can be at least as relevant as carcass weights and perhaps a better indicator for pastoralist systems in general. For this particular system, a measure of productivity in kilogrammes per square kilometre reveals a different picture: rather than being the typically failed system marred by suffering animals and low economic returns, reindeer herding in West Finnmark becomes the most productive in Norway.

\section{Supplementary information}

Supplementary information accompanies this paper at https://doi.org/10. 1186/s13570-020-00164-3.

Additional file 1. Data on carcass weights and NAO used in the analyses.

\section{Acknowledgements}

We thank our reindeer herders research partners in Finnmark for their collaboration through the years. We are also grateful to Øystein Holand for the constructive criticism on earlier versions of the article, and to the anonymous reviewers for inspiring and helpful comments.

\section{Authors' contributions}

All authors contributed to the conception, design, analysis, and writing up of this research. EJLB conducted the qualitative interviews. All authors read and approved the final manuscript. An earlier, shorter version of the article appeared in Norwegian in 2016; the article has undergone significant updates since then and added one co-author.

\section{Funding}

This research was partly funded by the Research Council of Norway through the project 'The Economics and Land-Use Conflicts of Sámi Reindeer Herding in Finnmark: Exploring the Alternatives (Dávggas)' with project number 215961.

\section{Availability of data and materials}

All data generated or analysed during this study are included in this published article and its supplementary information files.

\section{Ethics approval and consent to participate}

This research received an ethics approval from the Norwegian Centre for Research Data (NDS). Prior to interviews, all interviewees were informed about the purposes of the research and how the results would be used and gave their consent to participate.

Consent for publication

Not applicable

\section{Competing interests}

The authors declare that they have no competing interests.

\section{Author details}

${ }^{1}$ Department of International Environment and Development Studies (Noragric), Norwegian University of Life Sciences, Aas, Norway. ${ }^{2}$ Sámi University of Applied Sciences, Kautokeino, Norway.

Received: 23 December 2019 Accepted: 20 March 2020

Published online: 18 May 2020

\section{References}

Bårdsen, B.-J., and T. Tveraa. 2012. Density-dependence vs. density-independence - Linking reproductive allocation to population abundance and vegetation greenness. Journal of Animal Ecology 81: 364-376.

Behnke, R.H. 2000. Equilibrium and non-equilibrium models of livestock population dynamics in pastoral Africa: Their relevance to Arctic grazing systems. Rangifer 20 (2-3): 141-152.

Behnke, R.H., and C. Kerven. 1994. Redesigning for risk: Tracking and buffering environmental variability in Africa's rangelands. Natural Resource Perspectives. Vol. 1: 1-9. London: Overseas Development Institute.

Behnke, R.H., I. Scoones, and C. Kerven. 1993. Range ecology at disequilibrium. New models of natural variability and pastoral adaptation in African savannas. 
London: Overseas Development Institute \& International Institute for Environment and Development.

Benjaminsen, T.A., J. Borgenvik, E. Sjaastad, and A. Marin. 2016b. Reindeer density, productivity and efficiency improvement: On models, research, and politics (Norwegian: Reintetthet, produktivitet og effektivisering: om modeller, forsking og politikk). In Sámi reindeer pastoralism. Norwegian myths (Norwegian: Samisk reindrift. Norske myter), ed. T.A. Benjaminsen, I.M. Gaup Eira, and M.N. Sara, 69-85. Bergen: Fagbokforlaget.

Benjaminsen, T.A., H. Reinert, E. Sjaastad, and M.N. Sara. 2015. Misreading the Arctic landscape: A political ecology of reindeer, carrying capacities and overstocking in Finnmark, Norway. Norsk Geografisk Tidsskrift-Norwegian Journal of Geography 69 (4): 219-229.

Benjaminsen, T.A., M.N. Sara, and E. Sjaastad. 2016a. The myth of overgrazing on the Finnmark plateau (Norwegian: Myten om overbeiting på Finnmarksviddda). In Sámi reindeer pastoralism. Norwegian myths (Norwegian: Samisk reindrift. Norske myter), ed. T.A. Benjaminsen, I.M. Gaup Eira, and M.N. Sara, 87-105. Bergen: Fagbokforlaget

Bernes, C., K.A. Bråthen, B.C. Forbes, J.M.D. Speed, and J. Moen. 2015. What are the impacts of reindeer/caribou (Rangifer tarandus L.) on arctic and alpine vegetation? A systematic review. Environmental Evidence 4: 1-26.

Bidussi, M. 2014. Effects of climate change on lichen growth and metabolism. PhD thesis. Ås: Department of Ecology and Natural Resource Management,Norwegian University of Life Sciences.

Bjørklund, I. 2013. Domestication, reindeer husbandry and the development of Sámi pastoralism. Acta Borealia 30 (2): 174-189.

Borgenvik, E.J.L. 2014. "When you think like the state": The political ecology of pastoral modernization in Finnmark, Norway. Aas: MSc. Thesis, NMBU.

Callaghan, T.V., M. Johansson, R.D. Brown, P.Ya. Groisman, N. Labba, V. Radionov, R.S. Bradley, S. Blangy, O.G. Bulygina, T.R. Christensen, J.E. Colman, R.L.H. Essery, B.C. Forbes, M.C. Forchhammer, V.N. Golubev, R.E. Honrath, G.P. Juday, A.V. Meshcherskaya, G.K. Phoenix, J. Pomeroy, A. Rautio, D.A. Robinson, N.M. Schmidt, M.C. Serreze, V.P. Shevchenko, A.I. Shiklomanov, A.B. Shmakin, P. Sköld, M. Sturm, M. Woo, and E.F. Wood. 2011. Multiple effects of changes in Arctic snow cover. Ambio 40 (Supplement 1): 32-45.

Crittenden, P.D. 1999. Aspects of the ecology of mat-forming lichens. The Tenth Arctic Ungulate Conference- in Rangifer 20 (2-3): 127-139.

Eira, I.M.G., A. Oskal, I. Hanssen-Bauer, and S.D. Mathiesen. 2018. Snow cover and the loss of traditional indigenous knowledge. Nature Climate Change 8: 924936.

Eira, R.B.M. 2012. Using traditional knowledge in unpredictable critical events in reindeer husbandry - The case of Sámi reindeer husbandry in Western Finnmark, Norway and Nenets reindeer husbandry on Yamal peninsula, Yamal Nenets AO. Russia. Master Thesis. Tromsø: University of Tromsø.

Ellis, J.E., and D.M. Swift. 1988. Stability of African pastoral ecosystems: Alternate paradigms and implications for development. Journal of Range Management 41 (6): 450-459.

Fjellheim, P. 1967. Utvalg av slakterein. Reindriftsnytt 1 (2): 5-7.

Forbes, B., T. Kumpula, N. Meschtyb, R. Laptander, M. Marcias-Fauria, P. Zetterberg, M. Verdonen, A. Skarin, K.-Y. Kim, L.N. Boisvert, J.C. Stroeve, and A. Bartsch. 2016. Sea ice, rain-on-snow and tundra reindeer nomadism in Arctic Russia. Biology Letters 12(11): 20160466.

Forbes, B.C., M. Marcias-Fauria, and P. Zetterberg. 2010. Russian Arctic warming and 'greening' are closely tracked by tundra shrub willows. Global Change Biology 16 (5): 1542-1554.

Forbes, B.C., M.T. Turunen, T. Vuojala-Magga, P. Soppela, H. Kitti, and S. Rasmus. 2020. Changes in mountain birch forests and reindeer management: Comparing different sets of knowledge in Sápmi, northernmost Fennoscandia. Polar Record (published online: https://doi.org/10.1017/ S0032247419000834, 1-15).

Forchhammer, M.C., N.C. Stenseth, E. Post, \& N. Langvatn. 1998. Population Dynamics of Norwegian Red Deer: Density-Dependence and Climatic Variation. Proceedings: Biological Sciences 265 (1393), 341-350.

Goldstein, M.C., and C.M. Beall. 1990. Nomads of Western Tibet. The survival of a way of life. Berkeley: University of California Press.

Goldstein, M.C., and C.M. Beall. 1991. Change and continuity in nomadic pastoralism on the western Tibetan plateau. Nomadic Peoples 28: 105-122.

Helle, T., and I. Kojola. 2006. Population trends of semi-domesticated reindeer in Fennoscandia- Evaluation of explanations. Ecological Studies 184: 319-339. B. C. Forbes, M. Bölter, L. Müller-Wille, J. Hukkinen, F. Müller, N. Gunslay, Y. Konstatinov (Eds.), Reindeer management in northernmost Europe, SpringerVerlag, Berlin. Heildeberg.
Helle, T., and I. Kojola. 2008. Demographics in an alpine reindeer herd: Effects of density and winter weather. Ecography 31 (2): 221-230.

Hendrichsen, D.K., and N.J.C. Tyler. 2014. How the timing of weather events influences early development in a large mammal. Ecology 95 (7): 1737-1745.

Holand, $\varnothing$. 2003. Reindrift - Samisk næring i brytning mellom tradisjon og produksjon. Oslo: GAN Forlag AS.

Holand, Ø. 2007. Herd composition and slaughtering strategy in reindeer husbandry - Revisited. Rangifer Report No. 12.

Holand, Ø., A.A. Ims og, and R. Weladji. 2010. Scale-dependent effects of summer density on autumn mass in reindeer. Rangifer 30 (1): 15-29.

Hone, J., and T.H. Clutton-Brock. 2007. Climate, food, density and wildlife population growth rate. Journal of Animal Ecology 76: 361-367.

Ims, A.A., and A.J. Kosmo. 2001. Høyeste reintall for distriktene i Vest-Finnmark Høringsdokument. Alta: Reindriftsforvaltningen.

Jernsletten, J.L., and K. Klokov. 2002. Sustainable reindeer husbandry. Arctic council 2000-2002. Tromsø: Centre for Sami Studies.

Johnsen, K.I., and T.A. Benjaminsen. 2017. The art of governing and everyday resistance:" rationalization" of Sámi reindeer husbandry in Norway since the 1970s. Acta Borealia 34 (1): 1-25.

Johnsen, K.I., T.A. Benjaminsen, and I.M.G. Eira. 2017. Seeing like the state or like pastoralists? Conflicting narratives on the governance of Sámi reindeer herding in Finnmark, Norway. Norwegian Journal of Geography 69 (4): 230-241.

Kelman, I., Næss, M. 2019. Climate Change and Migration for Scandinavian Saami: A Review of Possible Impacts. Climate 7 (4):47.

Kolari, T.H.M., T. Kumpula, M. Verdonen, B.C. Forbes, and T. Tahvanainen. 2019. Reindeer grazing controls willows but has only minor effects on plant communities in Fennoscandian oroarctic mires. Arctic, Antarctic, and Alpine Research 51 (1): 506-520.

Lee, S.E., M.C. Press, J.A. Lee, T. Ingold, and T. Kurtilla. 2000. Regional effects of climate change on reindeer: A case study in the Muotkatunturi region in Finnish Lapland. Polar Research 19 (1): 99-105.

Lenvik, D. 1990. Flokkstrukturering- tiltak for lønnsom og ressurstilpasset reindrift. Rangifer 4: 21-25.

Lenvik, D., E. Bø, and A. Fjellheim. 1988. Relationship between the weight of reindeer calves in autumn and their mother's age and weight in the previous spring. Rangifer 8 (1): 20-24.

Lenvik, D., O. Granefjell, and J. Tamnes. 1982. Kalvetap fra en ny synsvinkel. Rangifer 2 (1): 62-74

Loison, A., R. Langvatn, and E.J. Solberg. 1999. Body mass and winter mortality in red deer calves: Disentangling sex and climate effects. Ecography 22 (1): 20-30.

Lundqvist, H. 2007. Range characteristics and productivity determinants fore reindeer husbandry in Sweden. PhD thesis. Uppsala: Agricultural University of Sweden.

Lybbert, T.J., C.B. Barrett, S. Desta, and D.L. Coppock. 2004. Stochastic wealth dynamics and risk management among a poor population. Economic Journal 114: 750-777.

Magga, O.H., Mathiesen, S.D., Corell, R.W. \& A. Oskal. 2009. Reindeer herding, traditional knowledge, and adaptation to climate change and loss of grazing land. Arctic Council. SDWG ( http://hdl.handle.net/11374/43 . Accessed 5 Feb 2020).

Magga, O.H., S.D. Mathiesen, R.W. Corell, and A. Oskal. 2011. Reindeer herding, traditional knowledge and adaptation to climate change and loss of grazing land. Kautokeino: Association of World Reindeer Herders.

Marin, A. 2006. Confined and sustainable? A critique of recent pastoral policy for reindeer herding in Finnmark, Northern Norway. Nomadic Peoples 10: 209232.

Marin, A. 2008. Between cash cows and golden calves: Adaptations of Mongolian pastoralism in the 'Age of the market'. Nomadic Peoples 12 (2): 75-101.

Marin, A. 2010. Chasing the rain. Mongolian pastoralists climate change vulnerability and adaptation in 'the Age of the Market'. PhD Thesis. Bergen: University of Bergen.

Marin, A. 2019. Volatility: Understanding global capitalism and climate change vulnerability in Mongolia. In Climate, capitalism and communities. An anthropology of environmental overheating, ed. A. Stensrud and T.H. Eriksen, 76-95. London: Pluto Press.

Marin, A., and I. Bjørklund. 2015. A tragedy of errors? Institutional dynamics and land tenure in Finnmark, Norway. International Journal of the Commons 9 (1): 19-40.

Marin, A., and I. Bjørklund. 2016. Is the Finnmark plateau a commons (Norwegian: Er Finnmarksvidda en allmenning?). In Sámi Reindeer Pastoralism. Norwegian myths (Norwegian: Samisk reindrift. Norske myter), ed. T.A. Benjaminsen, I.M. Gaup Eira, and M.N. Sara, 107-127. Bergen: Fagbokforlaget. 
Morton, J., and D. Barton. 2002. Destocking as a drought-mitigation strategy: Clarifying rationales and answering critiques. Disasters 26 (3): 213-228.

Mysterud, A., N.C. Stenseth, N.G. Yoccoz, R. Langvatn, and G. Stenheim. 2001. Nonlinear effects of large-scale climatic variability on wild and domestic herbivores. Nature 410 (6832): 1096-1099.

Næss, M.W., and B.-J. Bårdsen. 2010. Environmental stochasticity and long-term livestock viability - Herd-accumulation as a risk reducing strategy. Human Ecology 38: 3-17.

Næss, M.W., and B.-J. Bårdsen. 2013. Why herd size matters - Mitigating the effects of livestock crashes. PLoS One 8 (8): e70161.

Nielsen, K. \& A. Ulve. 2018. Fjellreindrifta i Finland på begynnelsen av 1900-tallet (Norwegian: "Mountain reindeer herding at the start of the 20th century"). Publications of the Giellagas Institute. 17. Oulu: University of Oulu. 332 p.

Paine, R. 1994. Herds of the tundra. A portrait of Saami reindeer pastoralism. Washington and London: Smithsonian Institution Press.

Paine, R. 2009. Camps of the tundra. Politics through reindeer among Saami pastoralists. Oslo: Instituttet for Sammenlignende kulturforskning.

Petorrelli, N., R. Weladji, Ø. Holand, A. Mysterud, H. Breie og, and N. Chr Stenseth. 2005. The relative role of winter and spring conditions: Linking climate and landscape-scale plant phenology to alpine reindeer body mass. Biology Letters 1 (1): 24-26.

Post, E., and M.D. Forchhammer. 2002. Synchronization of animal population dynamics by large-scale climate. Nature 420: 168-171.

Post, E., N.C. Stenseth, R. Langvatn, and J.-M. Fromentin. 1997. Global climate change and phenotypic variation among red deer cohorts. Proceedings of the Royal Society of London 264: 1317-1324.

Provenza, F.D., and D.F. Balph. 1987. Diet learning by domestic ruminants: Theory, evidence and practical implications. Applied Animal Behaviour Science 18: 211-232.

Regjeringen 2019. Reindrift. https://www.regjeringen.no/no/tema/mat-fiske-oglandbruk/reindrift/reindrift/id2339774/

Reindriftsforvaltningen. 2010. Account of resources in reindeer industry. For the period 1 April 2008-31 March 2009. http://www.reindrift.no/asset/1627/1/162 7 1.pdf

Reindriftsforvaltningen. 2013. Ressursregnskap for reindriftsnæringen for reindriftsåret 1. April 2011-31. Mars 2012.

Reindriftsnytt. 2013. Reindriftsforvaltningen presiserer: For økt lønnsomhet i reindrifta - slakt mer kalv! Reindriftsnytt 3: 34-39.

Reinert, H., and T.A. Benjaminsen. 2015. Conceptualising resilience in Norwegian Sámi reindeer pastoralism. Resilience: International Policies, Practices and Discourses 3 (2): 95-112.

Rist, L., A. Felton, L. Samuelsson, C. Sanström, and O. Rosvall. 2013. A new paradigm for adaptive management. Ecology and Society 18 (4): 63-72.

Robinson, S., and E.J. Milner-Gulland. 2003. Political change and factors limiting numbers of wild and domestic ungulates in Kazakhstan. Human Ecology 31 (1): $87-110$

Roe, E., L. Huntsinger, and K. Labnow. 1998. High reliability pastoralism. Journal of Arid Environments 39: 39-55.

Sæther, B.-E. 1997. Environmental stochasticity and population dynamics of large herbivores: A search for mechanisms. TREE 12: 143-149.

Sandford, S. 1995. Improving the efficiency of opportunism: New directions for pastoral development. In Living with uncertainty: New directions in pastoral development in Africa, ed. I. Scoones. London: Intermediate Technology Publications.

Sara, M.N. 2001. The reindeer - An asset from the wind. Reindeer herding's adaptation forms in Kautokeino [in Norwegian: Reinen- et gode fra vinden. Reindriftens tilpasningsformer i Kautokeino]. Karasjok: Davvi Girji.

Sayre, N.F. 2017, 288. The politics of scale. A history of rangeland science. Chicago: University of Chicago Press.

Scoones, I. 1995. New directions in pastoral development in Africa. In Living with uncertainty: New directions in pastoral development in Africa, ed. I. IN SCOONES. London: Intermediate Technology Publications.

Skogland, T. 1986. Density dependent food limitation and maximal production in wild reindeer herds. The Journal of Wildlife Management 50 (2): 314-319.

Skum, E.R., Turi, J.M., Moe, L., Eira, I.M.G., and S.D. Mathiesen. 2016. The role of the buck and the castrate in the reindeer herd (Norwegian: Reinoksens og kastratens rolle i reinflokken). In Benjaminsen, T.A., Gaup Eira, I.M. and Sara, M. N. (eds). Sámi reindeer pastoralism. Norwegian myths (Norwegian: Samisk reindrift. Norske myter), Fagbokforlaget, Bergen. pp. 129-142,
Stamps, J.A., and R.R. Swaisgood. 2007. Someplace like home: Experience, habitat selection and conservation biology. Applied Animal Behaviour Science 102: 392-409.

Tømmervik, H., B. Johansen, J.Å. Riseth, S.R. Karlsen, B. Solberg, and K.A. Høgda. 2009. Above ground biomass changes in the mountain birch forests and mountain heaths of Finnmarksvidda, northern Norway, in the period 19572006. Forest Ecology and Management 257 (1): 244-257.

Turi, Johan. 2011. [1910] Min bok om samene. Kárášjohka/Karasjok: [Muittalus sámiid birra] CálliidLágádus.

Tveito, O.E. 2014. Klimaendringer og betydning for skogbruket. Norwegian Meteorological Institute Report no. 25/2014. 49 pp. (https://bit.ly/32TtTYh, Accessed 24 Oct 2019)

Tyler, N.J.C. 1998. Reindeer pastures at disequilibrium. Rangifer, Report no. 2.

Tyler, N.J.C. 2010. Climate, snow, ice, crashes, and declines in populations of reindeer and caribou (Rangifer tarandus L.). Ecological Monographs 80 (2): 197-219.

Uboni, A., Horstkotte, T., Kaarlejärvi, E., Sévêque, A., Stammler, F, Olofsson, J., Forbes, B.C., \& JonMoen, 2016. Long-term trends and role of climate in the population dynamics of Eurasian reindeer. PLoS One, 2016, doi: https://doi. org/10.1371/journal.pone.0158359.

Vikhamar-Schuler, D., K. Isaksen, J.E. Haugen, H. Tømmervik, B. Luks, T.V. Schuler, and J.W. Bjerke. 2016. Changes in winter warming events in the Nordic Arctic Region. Journal of Climate 29: 6223-6244.

Villmo, L. 1967. Kan vi gjøre reindriften mer lønnsom? Reindriftsnytt 1 (1): 3-5 og $8-10$.

Vistnes, I., Ch. Nellemann, and K. Strøm Bull. 2004. Inngrep i reinbeiteland. Biologi jus og strategier i utbyggingssaker. NINA Thematic Issue 26, 67 https://www. nina.no/archive/nina/PppBasePdf/temahefte/26\%20.pdf. Accessed 25 Sept 2019.

Weladji, R., and $\varnothing$. Holand. 2003. Global climate change and reindeer: Effects of winter weather on the autumn weight and growth of calves. Oecologia 136 (2): 317-323.

Weladji, R.B., D.R. Klein, $\varnothing$. Holand, and A. Mysterud. 2002. Comparative response of Rangifer tarandus and other northern ungulates to climatic variability. Rangifer 22: 33-50.

Westoby, M., B. Walker, and I. Noy-Meir. 1989. Opportunistic management of rangelands not at equilibrium. Journal of Range Management 42 (4): 266-274.

Yeh, E.T., Y. Nyima, K.A. Hopping, and J.A. Klein. 2014. Tibetan pastoralists' vulnerability to climate change: A political ecology analysis of snowstorm coping capacity. Human Ecology 42 (1): 61-74.

Yoccoz, N.G., A. Mysterud, R. Langvatn, and N.C. Stenseth. 2002. Age- and densitydependent reproductive effort in male red deer. Proceedings of the Royal Society of London. Series B 269: 1523-1529.

\section{Publisher's Note}

Springer Nature remains neutral with regard to jurisdictional claims in published maps and institutional affiliations.

\section{Submit your manuscript to a SpringerOpen ${ }^{\circ}$ journal and benefit from:}

- Convenient online submission

- Rigorous peer review

- Open access: articles freely available online

- High visibility within the field

- Retaining the copyright to your article

Submit your next manuscript at $>$ springeropen.com 